\title{
PENALARAN MATEMATIS MAHASISWA DALAM MEMECAHKAN MASALAH ANALISIS REAL BERDASARKAN KEMAMPUAN BERPIKIR INTUITIF
}

\author{
Fatriya Adamura $^{1}$, Vera Dewi Susanti ${ }^{2}$ \\ ${ }^{1,2}$ Universitas PGRI Madiun
}

\begin{abstract}
Mathematical reasoning ability is needed by students both in the process of understanding mathematics and in everyday life context. In fact, Indonesian students' ability in the field of mathematics is still very low. Referring to the fact, this study is attempted to determine students' mathematical reasoning in solving real analysis problems based on their ability to think intuitively. This study is a qualitative descriptive research. The data sources in this study are college students. Data are collected through written tests and interview. Data analysis in this study is carried out by stages of data reduction, data presentation, and conclusion. The results show that (1) Students with high intuitive thinking skills in real analysis problem solving have a tendency to implement mathematical reasoning perfectly. They are able to carry out mathematical reasoning at each stage of solving real analysis problems. (2) Students with medium intuitive thinking ability in solving real analysis problem have a tendency to implement mathematical reasoning less perfectly. They are not able to carry out mathematical reasoning at the stage of solving problems according to plan and rechecking it again. (3) Students with low intuitive thinking skill in solving real analysis problem have a tendency to implement mathematical reasoning imperfectly. They are unable to carry out mathematical reasoning at the stage of planning solution and solving problem.
\end{abstract}

Keywords:mathematical reasoning, solving problem, intuitive.

\section{PENDAHULUAN}

Salah satu materi yang dipelajari di jenjang sekolah mulai dari jenjang dasar sampai atas adalah materi Matematika. Materi matematika merupakan materi yang sangat penting dalam kehidupan. Matematika sangat dibutuhkan di berbagai jenis kegiatan ataupun pekerjaan. Hal ini sejalan dengan pendapat Marsigit (2012) yang memandang bahwa matematika merupakan pemecahan masalah. Matematika selalu dibutuhkan oleh manusia dalam setiap pemecahan masalah yang dilakukan.

Erman Suherman, dkk (dalam Wulandari, 2011) menyatakan bahwa matematika juga memiliki peran penting dalam pemenuhan kebutuhan praktis dan memecahkan masalah dalam kehidupan sehari-hari misalnya mengumpulkan, mengolah, menyajikan, dan menafsirkan data, menghitung isi dan berat. Bagi siswa, matematika dipelajari untuk memahami bidang ilmu lain seperti fisika, kimia, arsitektur, farmasi, geografi, dan ekonomi. Hal tersebut menunjukkan betapa pentingnya matematika, sehingga harus dipelajari di setiap jenjang pendidikan.

Matematika yang dipelajari di jenjang sekolah disebut matematika sekolah (Erman Suherman dkk dalam Wulandari, 2011). Matematika yang dipelajari di jenjang sekolah disesuaikan dengan perkembangan kognitif, afektif, dan psikomotorik siswa. 
Penyelenggaraan pendidikan matematika di sekolah Indonesia saat ini diatur dalam Kurikulum Tingkat Satuan Pendidikan (KTSP). KTSP mengamanatkan bahwa salah satu aspek penting dalam pembelajaran matematika sekolah adalah pengembangan kemampuan penalaran siswa. Hal ini ditunjukkan dengan salah satu tujuan mata pelajaran Matematika adalah agar siswa memiliki kemampuan untuk menggunakan penalaran pada pola dan sifat, melakukan manipulasi matematika dalam membuat generalisasi, menyusun bukti, atau menjelaskan gagasan dan pernyataan matematika (http://www.puskur.net /download/si/smp/Matematika.pdf).

Penalaran merupakan proses berpikir dalam menarik kesimpulan yang berupa pengetahuan untuk memperoleh kebenaran (Marsigit, 2012). Penalaran merupakan salah satu karakteristik dari manusia. Karakteristik manusia yang lain adalah merasa, bersikap, dan bertindak. Penalaran yang dilakukan seseorang untuk memperoleh kebenaran merupakan gabungan dari penalaran deduktif dan induktif. Penalaran deduktif merupakan penalaran yang dilakukan dari umum ke khusus, sedangkan penalaran induktif merupakan penalaran yang dilakukan dari khusus ke umum.

Penalaran adalah suatu proses atau suatu aktivitas berpikir untuk menarik suatu kesimpulan atau proses berpikir dalam rangka membuat suatu pernyataan baru yang benar berdasarkan pada beberapa pernyataan yang kebenarannya telah dibuktikan atau diasumsikan sebelumnya. Materi matematika dan penalaran matematika merupakan dua hal yang tidak dapat dipisahkan. Materi matematika dipahami melalui penalaran, dan penalaran dipahami dan dilatihkan melalui belajar matematika

Kemampuan penalaran matematis diperlukan siswa baik dalam proses memahami matematika maupun dalam kehidupan sehari-hari. Dalam pembelajaran matematika, kemampuan penalaran berperan baik dalam pemahaman konsep dan pemecahan masalah. Dalam kehidupan sehari-hari, kemampuan bernalar berguna pada saat menyelesaikan permasalahan-permasalahan yang terjadi baik dalam lingkup pribadi, masyarakat dan institusi-institusi sosial lain yang lebih luas.

Pada kenyataannya, kemampuan Indonesia di dunia pendidikan dalam bidang matematika masih sangat rendah. Hal ini didukung oleh fakta dari hasil tes TIMSS 2003 yang menunjukkan bahwa siswa Indonesia berada pada peringkat 35 dari 46 negara khususnya pada penalaran matematikanya (Rustandi, 2013). Hasil penelitian Priatna (dalam Rustandi, 2013) menyatakan bahwa kualitas kemampuan penalaran dan pemahaman matematika siswa SMP Negeri di kota Bandung masih belum memuaskan yaitu masing-masing sekitar 49\% dan 50\% dari skor ideal. 
Salah satu mata kuliah yang dipelajari di jenjang Pendidikan Matematika adalah Analisis Real. Berdasarkan pengalaman dosen Analisis Real, kemampuan mahasiswa dalam mempelajari Analisis Real masih kurang. Rata-rata nilai akhir mahasiswa pada mata kuliah Analisis Real juga kurang. Mahasiswa selalu menyampaikan bahwa mahasiswa sulit memahami materi Analisis Real. Kemampuan berpikir intuitif juga sangat penting untuk dimiliki mahasiswa (Nasution, 2006).

Fakta yang telah diuraikan menunjukkan bahwa kemampuan penalaran matematika mahasiswa di Indonesia masih rendah. Hal tersebut tentunya tidak sesuai dengan kodisi yang diharapkan, yaitu kemampuan penalaran matematika mahasiswa tinggi. Masalah tersebut harus dicarikan solusinya. Solusi dari masalah yang telah diuraikan adalah dengan menggunakan pembelajaran yang memfasilitasi mahasiswa untuk melakukan penalaran matematika. Di sisi lain, kemampuan mahasiswa dalam memahami materi Analisis Real juga rendah. Dan kemampuan berpikir intuitif mahasiswa penting untuk diketahui. Hal ini karena kemampuan berpikir intuitif diperlukan untuk mempelajari matematika tingkat tinggi.

Pengembangan kemampuan penalaran matematis siswa berkaitan dengan pendekatan pembelajaran yang diterapkan (Wulandari, 2011). Pengembangan kemampuan penalaran memerlukan pembelajaran yang memfasilitasi proses berfikir, proses bernalar, sikap kritis siswa dan bertanya. Pembelajaran yang dilakukan untuk mengembangkan penalaran matematis siswa dirancang sesuai dengan kemampuan penalaran siswa. Berdasarkan hal tersebut, maka seorang guru yang ingin melaksanakan pembelajaran yang memfasilitasi siswa untuk melaksanakan penalaran matematika harus mengetahui kemampuan penalaran matematika siswa yang diajar.

Mulis (Suyadi dalam Rustandi, 2013) menyampaikan bahwa berdasarkan laporan hasil studi TIMSS 1999 yang dilakukan di 38 negara (termasuk Indonesia), antara lain menjelaskan bahwa sebagian besar pembelajaran matematika belum berfokus pada pengembangan penalaran matematis siswa. Paradigma mengajar di Indonesia memiliki ciri-ciri antara lain: guru aktif sedangkan siswa pasif, pembelajaran berpusat kepada guru, guru mentransfer pengetahuan ke pikiran siswa, Marpaung (Qodariah dalam Rustandi, 2013). Penalaran matematis juga harus dimiliki oleh mahasiswa calon guru matematika. Uraian tersebut mendorong peneliti untuk mendeskripsikan penalaran matematis mahasiswa dalam memecahkan masalah Analisis Real berdasarkan kemampuan berpikir intuitif.

Berdasarkan uraian di atas, maka masalah dalam penelitian ini adalah: Bagaimana penalaran matematis mahasiswa dalam memecahkan masalah Analisis Real 
berdasarkan kemampuan berpikir intuitif? Berdasarkan rumusan masalah tersebut, maka penelitian ini bertujuan untuk mengetahui penalaran matematis mahasiswa dalam memecahkan masalah analisis real berdasarkan kemampuan berpikir intuitif. Penelitian ini diharapkan dapat bermanfaat untuk mengembangkan penelitian-penelitian yang menyangkut penalaran matematis mahasiswa. Selain itu, juga dapat digunakan sebagai acuan untuk melakukan penelitian yang relevan pada masa yang akan datang.

\section{METODE PENELITIAN}

Pendekatan penelitian yang digunakan oleh peneliti adalah metode penelitian kualitatif. Metode ini digunakan untuk meneliti kondisi objek yang alamiah. Pengambilan sampel sumber data dilakukan secara purposive, teknik pengumpulan dengan triangulasi, analisis data bersifat induktif/kualitatif, dan hasil penelitian kualitatif lebih menekankan makna daripada generalisasi (Moleong, 2012). Jenis penelitian yang digunakan adalah penelitian kualitatif deskriptif. Penelitian deskriptif melakukan analisis hanya sampai pada taraf deskripsi, yaitu menganalisis dan menyajikan data secara sistematik, sehingga dapat lebih mudah untuk dipahami dan disimpulkan. Penelitian dilakukan untuk mengetahui penalaran matematis mahasiswa dalam memecahkan masalah Analisis Real ditinjau dari kemampuan mahasiswa dalam berpikir intuitif.

Pada penelitian ini, data secara langsung diperoleh dari mahasiswa Prodi Pendidikan Matematika FKIP UNIPMA yang sudah menerima mata kuliah Analisis Real pada semester genap tahun akademik 2017/2018. Mahasiswa yang dijadikan subyek penelitian adalah mahasiswa kelas VI A. Mahasiswa kelas VI A diambil subyek sebanyak 6 mahasiswa kemudian diberi tes kemampuan berpikir intuitif dan diwawancarai. 6 mahasiswa yang dipilih adalah 2 mahasiswa dengan kemampuan berpikir intuitif tinggi, 2 mahasiswa dengan kemampuan berpikir intuitif sedang, dan 2 mahasiswa dengan kemampuan berpikir intuitif rendah. Teknik pengumpulan data yang digunakan oleh peneliti adalah metode tes, interview (wawancara), dokumentasi dan observasi (Sugiyono, 2013).

Teknik pemeriksaan keabsahan data dilakukan dengan teknik triangulasi. Teknik triangulasi adalah teknik pemeriksaan keabsahan data yang memanfaatkan sesuatu yang lain. Triangulasi yang dilakukan oleh peneliti pada penelitian ini, adalah: triangulasi metode. Analisis dilakukan secara berkelanjutan dan meliputi tiga macam kegiatan, yaitu: reduksi data (data reduction), penayangan data (data display), dan verifikasi data (data verification)(Miles and Huberman dalam Sunarto, 2001). 
Berikut ini disajikan tabel deskriptor dan indikator penalaran matematis mahasiswa dalam memecahkan masalah.

Tabel 1. Deskriptor Dan Indikator Penalaran Matematis Mahasiswa DalamMemecahkan Masalah

\begin{tabular}{|c|c|c|}
\hline $\begin{array}{c}\text { Kemampuan Penalaran } \\
\text { Matematis }\end{array}$ & Deskriptor & $\begin{array}{l}\text { Langkah } \\
\text { Pemecahan } \\
\text { Masalah } \\
\end{array}$ \\
\hline \multirow{3}{*}{$\begin{array}{l}\text { A. Kemampuan } \\
\text { menyajikan pernyataan } \\
\text { matematika secara lisan, } \\
\text { tertulis, gambar, dan } \\
\text { diagram }\end{array}$} & $\begin{array}{l}\text { 1. Menuliskan apa yang } \\
\text { diketahui dan yang ditanyakan }\end{array}$ & \multirow[t]{3}{*}{$\begin{array}{l}\text { Memahami } \\
\text { masalah }\end{array}$} \\
\hline & $\begin{array}{l}\text { 2. Menyampaikan apa yang } \\
\text { diketahui dan yang ditanyakan } \\
\text { secara lisan }\end{array}$ & \\
\hline & $\begin{array}{l}\text { 3. Menggambarkan } \\
\text { yang diketahui dan } \\
\begin{array}{l}\text { yang } \\
\text { ditanyakan dalam bentuk } \\
\text { diagram }\end{array} \\
\end{array}$ & \\
\hline $\begin{array}{l}\text { B. Kemampuan } \\
\begin{array}{l}\text { mengajukan dugaan } \\
\text { (conjectures) }\end{array}\end{array}$ & 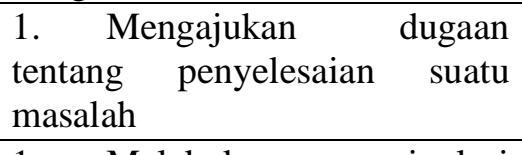 & $\begin{array}{l}\text { Merencanakan } \\
\text { penyelesaian }\end{array}$ \\
\hline $\begin{array}{l}\text { C. Kemampuan } \\
\text { melakukan manipulasi } \\
\text { matematika }\end{array}$ & $\begin{array}{l}\text { 1. Melakukan manipulasi } \\
\text { aljabar pada penyelesaian } \\
\text { masalah matematika }\end{array}$ & \multirow[t]{3}{*}{$\begin{array}{l}\text { Menyelesaikan } \\
\text { masalah sesuai } \\
\text { rencana }\end{array}$} \\
\hline \multirow[b]{2}{*}{$\begin{array}{l}\text { D. Kemampuan } \\
\text { menarik kesimpulan, } \\
\text { menyusun bukti, } \\
\text { memberikan alasan atau } \\
\text { bukti terhadap beberapa } \\
\text { solusi }\end{array}$} & 1. Menyusun bukti atas & \\
\hline & $\begin{array}{l}\text { masalah matematika } \\
2 . \quad \text { Memberikan alasan atau } \\
\text { bukti terhadap beberapa solusi }\end{array}$ & \\
\hline $\begin{array}{l}\text { E. Kemampuan } \\
\text { menarik kesimpulan dari } \\
\text { pernyataan }\end{array}$ & $\begin{array}{l}\text { 1. Menarik kesimpulan dari } \\
\text { pernyataan }\end{array}$ & \multirow[t]{3}{*}{$\begin{array}{l}\text { Melakukan } \\
\text { pengecekan } \\
\text { kembali }\end{array}$} \\
\hline $\begin{array}{l}\text { F. Kemampuan } \\
\text { memeriksa kesahihan } \\
\text { suatu argumen }\end{array}$ & $\begin{array}{l}\text { 1. Memeriksa jawaban yang } \\
\text { telah didapatkan }\end{array}$ & \\
\hline $\begin{array}{l}\text { G. Kemampuan } \\
\text { menemukan pola atau } \\
\text { sifat dari gejala matematis } \\
\text { untuk membuat } \\
\text { generalisasi }\end{array}$ & $\begin{array}{l}\text { 1. Menemukan pola atau } \\
\text { sifat dari gejala matematis } \\
\text { untuk membuat generalisasi }\end{array}$ & \\
\hline
\end{tabular}

\section{HASIL DAN PEMBAHASAN}

Berdasarkan nilai tes soal kemampuan berpikir intuitif pada mata kuliah analisis real, maka dipilih 6 subjek yang terdiri dari 2 mahasiswa dengan kemampuan berpikir intuitif tinggi, 2 mahasiswa dengan kemampuan berpikir intuitif sedang, dan 2 mahasiswa dengan kemampuan berpikir intuitif rendah. Untuk selanjutnya akan disebut subjek I, subjek II, subjek III, subjek IV, subjek V, dan subjek VI. Adapun hasil penentuan subjek penelitian dapat dilihat pada Tabel 2 . 
Tabel 2. Hasil Penentuan Subjek Penelitian

\begin{tabular}{clccc}
\hline No & Nama Mahasiswa & Inisial & Subjek & $\begin{array}{c}\text { Tingkat Kemampuan } \\
\text { Berpikir Intuitif }\end{array}$ \\
\hline 1 & Meylani Yunita & MY & \multirow{2}{*}{ KBIT } & Tinggi \\
2 & Puput Mey Indrawati & PM & & Tinggi \\
\hline 3 & Ika Sukristini & IS & \multirow{2}{*}{ KBIS } & Sedang \\
4 & Agung Budi Prasetyo & AB & & Sedang \\
\hline 5 & Rahmatul Maghfiroh & RM & \multirow{2}{*}{ KBIR } & Rendah \\
6 & Rofi' Afif Nurwidianto & RA & & Rendah \\
\hline
\end{tabular}

Data penelitian dianalisis untuk memperoleh deskripsi penalaran matematis mahasiswa dalam memecahkan masalah analisis real ditinjau dari kemampuan berpikir intuitif. Pembahasan ini meliputi penalaran matematis mahasiswa dalam: (1) memahami masalah, (2) merencanakan penyelesaian, (3) menyelesaikan masalah sesuai rencana, (4) melakukan pengecekan kembali.

\section{A. Analisis Data Subjek dengan Kemampuan Berpikir Intuitif Tinggi (Subjek KBIT)}

1. Memahami masalah

Subjek KBIT dalam memahami masalah menuliskan hal yang diketahui dan yang ditanyakan. Subjek KBIT dapat menuliskan bahwa yang diketahui adalaha, b, c, $\mathrm{d} \in \mathbb{R}, \mathrm{a}<b$ dan $\mathrm{c} \leq \mathrm{d}$. Sedangkan pada yang ditanyakan, subjek KBIT dapat menuliskan bahwa yang ditanyakan $-(\mathrm{a}+\mathrm{b})=(-\mathrm{a})+(-\mathrm{b})$, jika $\mathrm{a}<b$ dan $\mathrm{c} \leq \mathrm{d}$, maka $\mathrm{a}+\mathrm{c}<b+d$, dan apakah kedua pernyataan berlaku untuk semua anggota himpunan bilangan Real. Hal tersebut sesuai dengan jawaban dari subjek KBIT sebagai berikut.

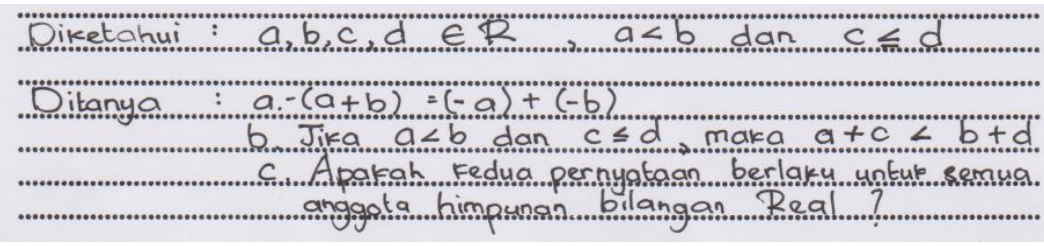

\section{Gambar 1. Jawaban Subjek KBIT}

Subjek KBIT juga dapat menentukan hal-hal yang diketahui sudah dapat digunakan untuk menjawab permasalahan yang ditanyakan pada soal. Hal ini dapat dilihat dari pekerjaan tertulis subjek KBIT yang mampu menyusun langkahlangkah pemecahan masalah dan melaksanakannya sehingga diperoleh hal yang ditanyakan, yaitu bukti dari dua pernyataan, yaitu $-(a+b)=(-a)+(-b)$ dan jika a $<b$ dan $\mathrm{c} \leq \mathrm{d}$, maka $\mathrm{a}+\mathrm{c}<b+d$. Berdasarkan hal tersebut, maka subjek KBIT mampu menuliskan apa yang diketahui dan yang ditanyakan, sehingga bisa dikatakan bahwa subjek KBIT mampu menyajikan pernyataan matematika secara lisan, tertulis, gambar, dan diagram. 
2. Merencanakan penyelesaian

Dari hasil pekerjaan tertulis subjek KBIT, peneliti merangkum langkah-langkah pemecahan masalah yang dilakukan, yaitu membuktikan bahwa $-(\mathrm{a}+\mathrm{b})=$ $(-\mathrm{a})+(-\mathrm{b})$ dan jika $\mathrm{a}<b$ dan $\mathrm{c} \leq \mathrm{d}$, maka $\mathrm{a}+\mathrm{c}<b+d$. Untuk membuktikan bahwa $-(a+b)=(-a)+(-b)$, subjek KBIT mampu membuat kaitan dari halhal yang diketahui, yaitu konsep $\mathrm{a}, \mathrm{b} \in \mathbb{R}$ dengan sifat anggota himpunan bilangan Real. Subjek KBIT mampu menuliskan $-(a+b)$ sebagai $(-1)(a+b)$, kemudian menerapkan sifat distributif perkalian terhadap penjumlahan, dan menerapkan kembali sifat $(-1)(a)=-a$. Subjek KBIT juga bisa membuktikan bahwa $(-1)(a)=-a$ secara lengkap beserta buktinya.

Untuk membuktikan bahwa jika $\mathrm{a}<b$ dan $\mathrm{c} \leq \mathrm{d}$, maka $\mathrm{a}+\mathrm{c}<b+d$, subjek KBIT mengambil dua kasus. Kasus yang pertama adalah jika $c=d$. Subjek KBIT mampu mengaitkan hal yang diketahui dengan yang akan dibuktikan, yaitu jika $\mathrm{a}<b$ dan $\mathrm{c}=\mathrm{d}$, maka $\mathrm{a}+\mathrm{c}<b+d$. Kasus yang kedua adalah jika $\mathrm{c}<d$. Pada kasus yang kedua ini, subjek KBIT mampu mengaitkan antara yang diketahui dengan yang akan dibuktikan. Untuk membuktikan $\mathrm{a}+\mathrm{c}<b+d$, subjek KBIT terlebih dahulu menuliskan bahwa $\mathrm{a}+\mathrm{c}<b+c$, kemudian $\mathrm{a}+\mathrm{c}<b+c<b+$ d. Uraian tersebut menunjukkan bahwa subjek KBIT mampu mengajukan dugaan tentang penyelesaian suatu masalah, sehingga bisa dikatakan bahwa subjek KBIT mampu mengajukan dugaan.

3. Menyelesaikan masalah sesuai rencana

Subjek KBIT dapat menyelesaikan masalah sesuai rencana yang telah dibuat dengan lancar meskipun pada beberapa bagian terjadi kesalahan. Langkah-langkah yang ditempuh subjek KBIT dalam melaksanakan penyelesaian masalah yang telah direncanakan dapat dijelaskan sebagai berikut.

Subjek KBIT dapat menguraikan langkah-langkah yang ditempuh untuk membuktikan $-(\mathrm{a}+\mathrm{b})=(-\mathrm{a})+(-\mathrm{b})$. Untuk membuktikan $-(\mathrm{a}+\mathrm{b})=(-\mathrm{a})+$ $(-\mathrm{b})$, subjek KBIT menggunakan konsep sifat-sifat anggota himpunan bilangan Real. Subjek KBIT terlebih dahulu menuliskan $-(a+b)$ sebagai $(-1)(a+b)$, kemudian $(-1) \mathrm{a}+(-1) \mathrm{b}$ dan $(-\mathrm{a})+(-\mathrm{b})$. Hal ini terlihat dari pekerjaan tertulis subjek KBIT berikut.

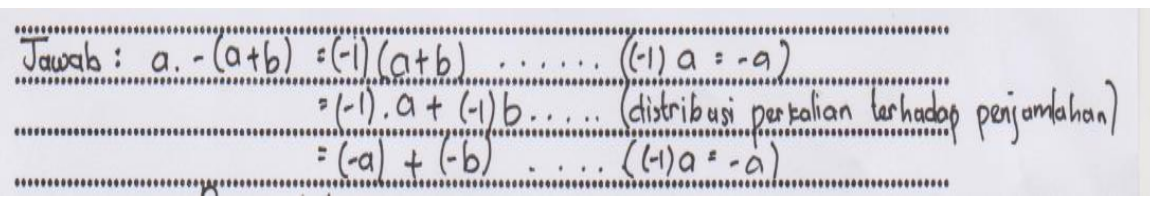

Gambar 2. Jawaban Subjek KBIT 
Uraian tersebut menunjukkan bahwa subjek KBIT mampu melakukan manipulasi aljabar pada penyelesaian masalah matematika sehingga dapat dikatakan bahwa subjek KBIT mampu melakukan manipulasi matematika.

Selain itu, subjek KBIT juga mampu membuktikan bahwa $(-1) \mathrm{a}=-\mathrm{a}$. Dalam membuktikan $(-1) \mathrm{a}=-\mathrm{a}$, subjek KBIT menggunakan konsep sifat aljabar pada himpunan bilangan Real.

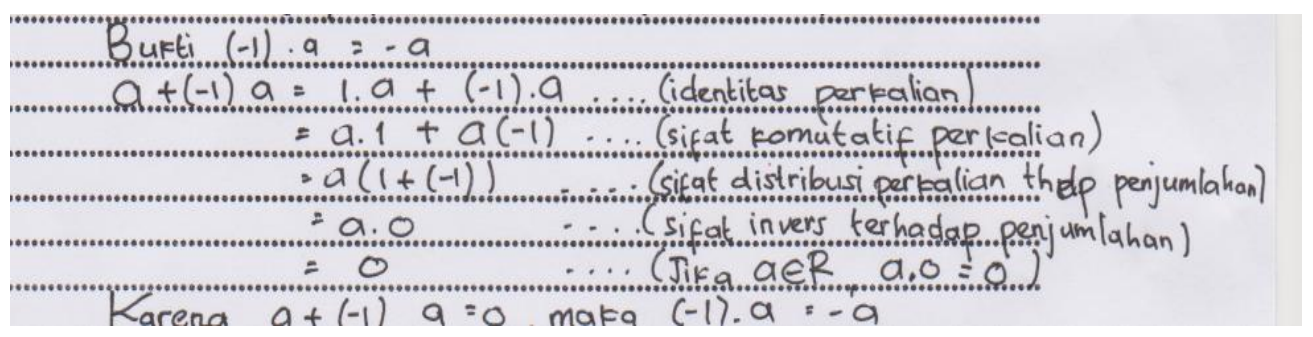

\section{Gambar 3. Jawaban Subjek KBIT}

Dalam pembuktian yang telah diuraikan, yaitu pembuktian $-(a+b)=$ $(-a)+(-b)$ dan $(-1) a=-a$, terlihat bahwa subjek KBIT selalu memberi alasan pada setiap langkah pembuktian yang dilakukan.

Selanjutnya, subjek KBIT dapat menguraikan langkah-langkah yang ditempuh untuk membuktikan jika $\mathrm{a}<b$ dan $\mathrm{c} \leq \mathrm{d}$, maka $\mathrm{a}+\mathrm{c}<b+d$. Dalam membuktikan jika a $<b$ dan $\mathrm{c} \leq \mathrm{d}$, maka $\mathrm{a}+\mathrm{c}<b+d$, subjek KBIT mengambil dua kasus. Kasus yang pertama adalah $\mathrm{c}=\mathrm{d}$. Pada kasus yang pertama ini, subjek KBIT mampu menuliskan bahwa jika $\mathrm{a}<b$ dan $\mathrm{c}=\mathrm{d}$, maka $\mathrm{a}+\mathrm{c}<b+d$. Subjek KBIT mampu mengaitkan yang diketahui dengan yang dibuktikan. Subjek KBIT mampu membuktikan pernyataan jika $\mathrm{a}<b$ dan $\mathrm{c}=\mathrm{d}$, maka $\mathrm{a}+\mathrm{c}<b+d$ meskipun bukti yang dituliskan kurang benar. Hal ini bisa dilihat dari hasil pengerjaan subjek KBIT berikut.

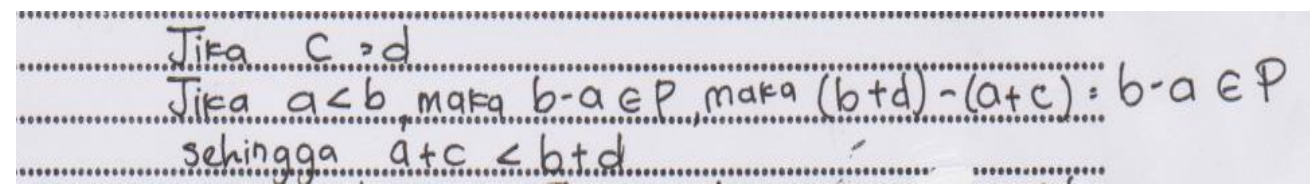

\section{Gambar 4. Jawaban Subjek KBIT}

Kasus yang kedua adalah $\mathrm{c}<d$. Pada kasus yang kedua ini, subjek KBIT mampu menuliskan bahwa jika $\mathrm{a}<b$ dan $\mathrm{c}<d$, maka $\mathrm{a}+\mathrm{c}<b+d$. Subjek KBIT mampu mengaitkan yang diketahui dengan yang dibuktikan. Subjek KBIT mampu menuliskan bahwa jika $\mathrm{a}<b$ dan $\mathrm{c}<d$, maka $\mathrm{a}+\mathrm{c}<b+c$, kemudian subjek KBIT menuliskan $\mathrm{a}+\mathrm{c}<b+c$ kemudian $\mathrm{a}+\mathrm{c}<b+d$. Subjek KBIT belum mampu membuktikan pernyataan jika a $<b$ dan $\mathrm{c}<d$, maka $\mathrm{a}+\mathrm{c}<b+$ $d$. Hal ini bisa dilihat dari hasil pengerjaan subjek KBIT berikut. 


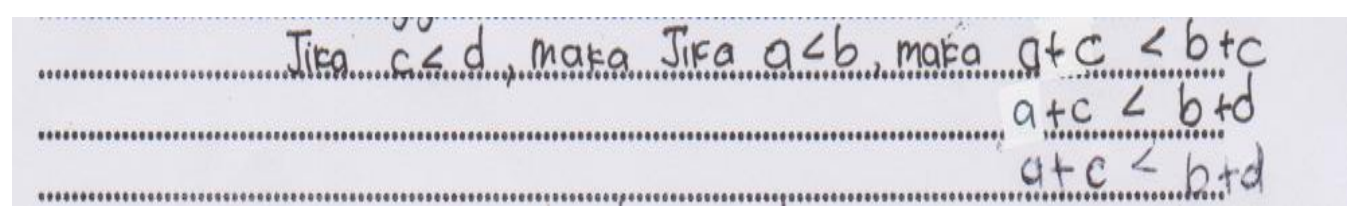

\section{Gambar 5. Jawaban Subjek KBIT}

Hasil pembuktian dari subjek KBIT tersebut menunjukkan bahwa subjek KBIT belum mampu menyusun bukti atas masalah matematika secara sempurna. Hal ini dapat disimpulkan dari ketidakmampuan subjek KBIT dalam membuktikan pernyataan jika $\mathrm{a}<b$ dan $\mathrm{c}<d$, maka $\mathrm{a}+\mathrm{c}<b+d$. Hal tersebut juga menunjukkan bahwa subjek KBIT juga belum mampu memberikan alasan atau bukti terhadap beberapa solusi secara sempurna. Subjek KBIT dikatakan kurang mampu menarik kesimpulan, menyusun bukti, memberikan alasan atau bukti terhadap beberapa solusi.

4. Melakukan pengecekan kembali

Pada tahap melakukan pengecekan kembali, subjek KBIT mampu menarik kesimpulan dari pernyataan. Subjek KBIT mampu menarik kesimpulan dari setiap pernyataan yang ada pada soal tes. Hal ini terlihat pada hasil pengerjaan subjek

$$
\text { Jadi }-(a+b)=(-a)+(-b) \quad \forall a, b \in \mathbb{R}
$$

Gambar 6. Jawaban Subjek KBIT

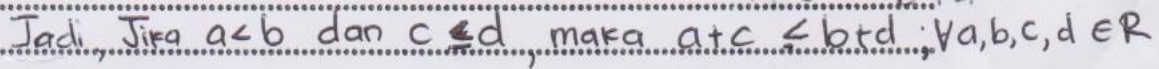

\section{Gambar 7. Jawaban Subjek KBIT}

Subjek KBIT memeriksa jawaban yang telah didapatkan. Hal ini terlihat dari hasil pengerjaan soal tes penalaran matematis oleh subjek KBIT yang benar dan teliti, yaitu tidak ditemukan adanya kesalahan jawaban. Hal tersebut menunjukkan bahwa subjek KBIT mampu memeriksa kesahihan suatu argumen. Subjek KBIT mampu menemukan pola atau sifat dari gejala matematis untuk membuat generalisasi. Hal tersebut ditunjukkan oleh hasil pengerjaan secara tertulis dari subjek KBIT sebagai berikut.

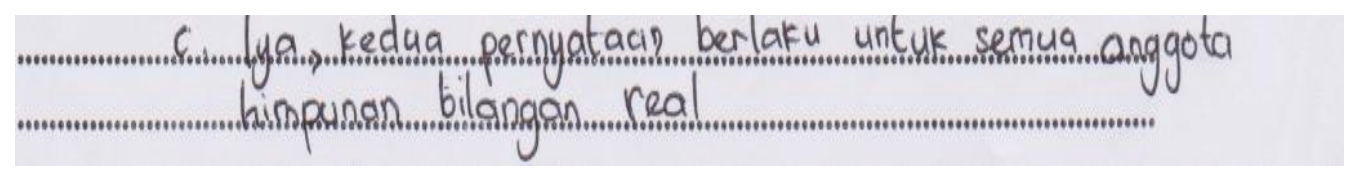

\section{Gambar 8. Jawaban Subjek KBIT}

B. Analisis Data Subjek dengan Kemampuan Berpikir Intuitif Sedang (Subjek KBIS)

1. Memahami masalah

Subjek KBIS dapat memahami masalah yang diberikan dengan menuliskan apa yang diketahui dan apa yang ditanyakan dari soal. Subjek KBIS dapat menuliskan 
bahwa yang diketahui adalah a, b, c, d $\in \mathbb{R}, \mathrm{a}<b$ dan $\mathrm{c} \leq \mathrm{d}$. Subjek KBIS juga dapat menuliskan bahwa yang ditanyakan $-(\mathrm{a}+\mathrm{b})=(-\mathrm{a})+(-\mathrm{b})$, jika $\mathrm{a}<\mathrm{b}$ dan $\mathrm{c} \leq \mathrm{d}$, maka $\mathrm{a}+\mathrm{c}<b+d$, dan apakah kedua pernyataan berlaku untuk semua anggota himpunan bilangan Real. Hal tersebut sesuai dengan jawaban dari subjek KBIS sebagai berikut.

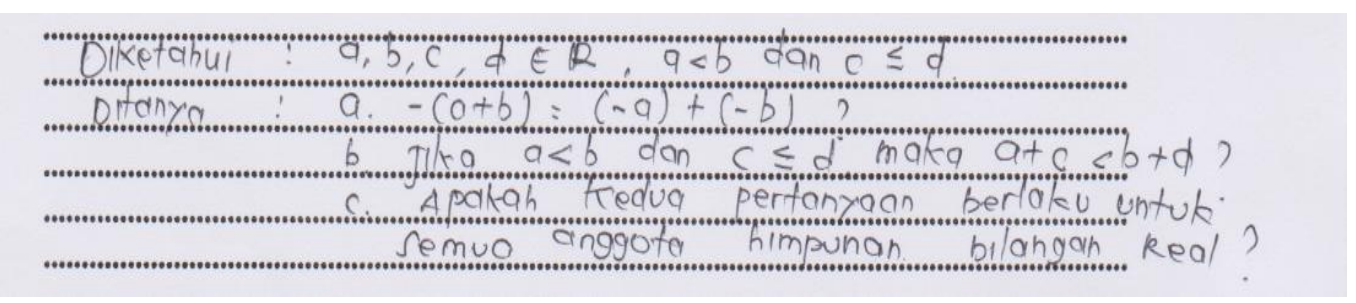

\section{Gambar 9. Jawaban Subjek KBIS}

Subjek KBIS dapat menentukan bahwa hal-hal yang diketahui sudah cukup untuk menjawab permasalahan yang ditanyakan pada soal. Hal ini dapat dilihat dari pekerjaan tertulis subjek KBIS yang mampu menyusun langkah-langkah pemecahan masalah dan melaksanakannya sehingga diperoleh hal yang ditanyakan. Berdasarkan hal tersebut, maka subjek KBIS mampu menuliskan apa yang diketahui dan yang ditanyakan, sehingga bisa dikatakan bahwa subjek KBIS mampu menyajikan pernyataan matematika secara lisan, tertulis, gambar, dan diagram.

2. Merencanakan penyelesaian

Dalam merencanakan penyelesaian masalah, yaitu membuktikan bahwa - $(\mathrm{a}+$ $\mathrm{b})=(-\mathrm{a})+(-\mathrm{b})$ dan jika $\mathrm{a}<b$ dan $\mathrm{c} \leq \mathrm{d}$, maka $\mathrm{a}+\mathrm{c}<b+d$, subjek KBIS mampu mengaitkan yang diketahui dengan yang ditanyakan dalam soal.

Untuk membuktikan bahwa $-(a+b)=(-a)+(-b)$, subjek KBIS memulai pembuktian dengan menuliskan $-(a+b)$ sebagai $(-1)(a+b)$, kemudian menerapkan sifat distributif perkalian terhadap penjumlahan, dan menerapkan kembali sifat $(-1)(a)=-a$. Subjek KBIS mampu menyimpulkan bahwa karena pernyataan $(-1)(\mathrm{a})=-\mathrm{a}$ belum ada pada aksioma himpunan bilangan real, maka subjek KBIS harus membuktikan bahwa $(-1)(a)=-a$. Bukti bahwa $(-1)(a)=-$ a dituliskan secara lengkap oleh subjek KBIS. Subjek KBIS juga mampu menyimpulkan bahwa pada bukti $(-1)(\mathrm{a})=-$ a terdapat pernyataan bahwa a. $0=0$. Subjek KBIS juga mampu membuktikan bahwa a. $0=0$ dengan benar karena pernyataan a. $0=0$ belum ada pada aksioma himpunan bilangan real.

Pada pembuktian yang kedua, yaitu jika $\mathrm{a}<b$ dan $\mathrm{c} \leq \mathrm{d}$, maka $\mathrm{a}+\mathrm{c}<$ $b+d$, subjek KBIS membagi $\mathrm{c} \leq \mathrm{d}$ menjadi dua kasus meskipun belum terlihat 
secara jelas. Kasus yang pertama adalah jika $\mathrm{c}=\mathrm{d}$. Pada kasus yang pertama ini, subjek KBIS menuliskan bahwa jika $\mathrm{a}<b$ dan $\mathrm{c}=\mathrm{d}$, maka $\mathrm{a}+\mathrm{c}<b+d$. Kasus yang kedua adalah jika $\mathrm{c}<d$. Pada kasus yang kedua ini, subjek KBIS mampu menuliskan $\mathrm{a}+\mathrm{c}<b+c<b+d$. Uraian tersebut menunjukkan bahwa subjek KBIS mampu mengajukan dugaan tentang penyelesaian suatu masalah, sehingga bisa dikatakan bahwa subjek KBIS mampu mengajukan dugaan.

3. Menyelesaikan masalah sesuai rencana

Berdasarkan rencana penyelesaian yang telah disusun, langkah pertama yang dilakukan subjek KBIS dalam membuktikan $-(a+b)=(-a)+(-b)$ adalah dengan menuliskan $-(\mathrm{a}+\mathrm{b})$ sebagai $(-1)(\mathrm{a}+\mathrm{b})$, kemudian subjek KBIS menerapkan sifat distributif perkalian terhadap penjumlahan sehingga didapat $(-1) a+(-1) b$ dan $(-a)+(-b)$. Pekerjaan tertulis subjek KBIS tersebut adalah sebagai berikut.

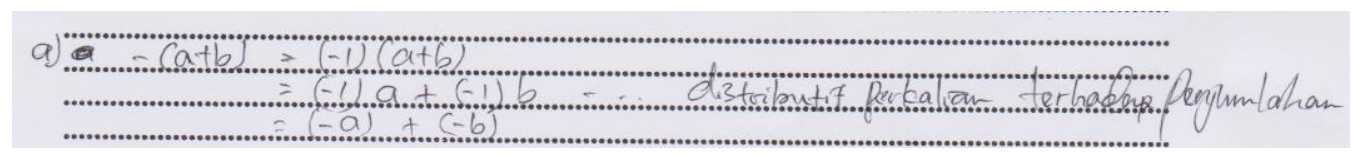

\section{Gambar 10. Jawaban Subjek KBIS}

Jawaban subjek KBIS seperti yang telah diuraikan di atas menunjukkan bahwa subjek KBIS belum mampu melakukan manipulasi aljabar pada penyelesaian masalah matematika. Subjek KBIS belum mampu menuliskan alasan dari setiap pembuktian yang dilakukan. Hal tersebut menunjukkan bahwa subjek KBIS belum mampu melakukan manipulasi matematika. Berikut ini adalah hasil pengerjaan tertulis dari subjek KBIS.

Pada pembuktian yang kedua, yaitu jika $\mathrm{a}<\mathrm{b}$ dan $\mathrm{c} \leq \mathrm{d}$, maka $\mathrm{a}+\mathrm{c}<$ $b+d$, subjek KBIS membagi $\mathrm{c} \leq \mathrm{d}$ menjadi dua kasus, yaitu $\mathrm{c}=\mathrm{d}$ dan $\mathrm{c}<d$. Pada kasus yang pertama, $\mathrm{c}=\mathrm{d}$, subjek KBIS menuliskan bahwa jika $\mathrm{a}<b$, maka $\mathrm{b}-\mathrm{a} \in \mathbb{P},(\mathrm{b}+\mathrm{a})-(\mathrm{a}+\mathrm{c})=\mathrm{b}-\mathrm{a} \in \mathbb{P}$ sehingga $\mathrm{a}+\mathrm{c}<b+d$. Subjek KBIS telah mampu mengaitkan antara yang diketahui dengan yang dibuktikan meskipun belum benar. Hal ini terlihat dari pernyataan bahwa $(b+a)-(a+c)=b-a \in$ P. Jawaban subjek KBIS tersebut adalah sebagai berikut.

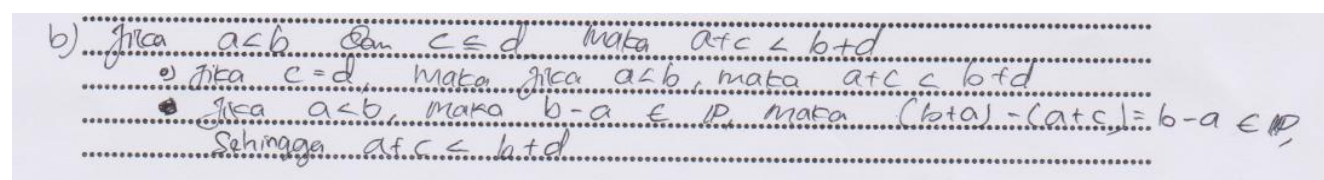

\section{Gambar 11. Jawaban Subjek KBIS}

Pada kasus yang kedua, yaitu $\mathrm{c}<d$, subjek KBIS menuliskan bahwa $\mathrm{a}+\mathrm{c}<b+c<b+d$ sehingga $\mathrm{a}+\mathrm{c}<b+d$. Pembuktian yang kedua ini masih 
belum sempurna karena subjek KBIS belum menuliskan alasan dari pembuktian yang dilakukan.

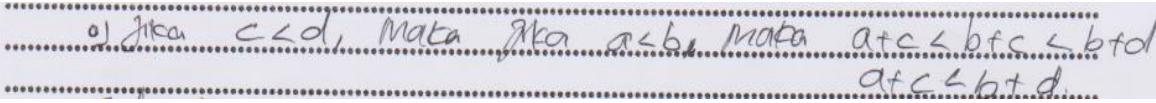

\section{Gambar 12. Jawaban Subjek KBIS}

Jawaban tertulis subjek KBIS menunjukkan bahwa subjek KBIS belum mampu menyusun bukti atas masalah matematika secara sempurna. Subjek KBIS belum mampu memberikan alasan atau bukti terhadap beberapa solusi. Hal ini dapat disimpulkan dari ketidakmampuan subjek KBIS dalam menerapkan sifat urutan pada himpunan bilangan Real pada pembuktian pernyataan jika $\mathrm{a}<b$ dan $\mathrm{c} \leq \mathrm{d}$, maka $\mathrm{a}+\mathrm{c}<b+d$. Subjek KBIS dikatakan belum mampu menarik kesimpulan, menyusun bukti, memberikan alasan atau bukti terhadap beberapa solusi.

4. Melakukan pengecekan kembali

Pada tahap melakukan pengecekan kembali, subjek KBIS belum mampu menarik kesimpulan dari pernyataan dengan sempurna. Subjek KBIS mampu menarik kesimpulan dari pembuktian jika $\mathrm{a}<b$ dan $\mathrm{c} \leq \mathrm{d}$, maka $\mathrm{a}+\mathrm{c}<b+d$, tetapi subjek IV tidak menarik kesimpulan dari pembuktian $-(a+b)=(-a)+(-b)$. Hal ini terlihat pada hasil pengerjaan subjek IV sebagai berikut.

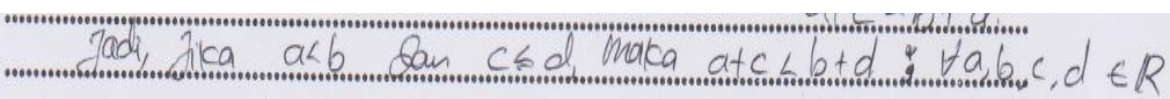

\section{Gambar 13. Jawaban Subjek KBIS}

Subjek KBIS tidak memeriksa jawaban yang telah didapatkan. Hal ini terlihat dari hasil pengerjaan soal tes penalaran matematis oleh subjek KBIS yang masih belum benar yaitu ditemukan adanya kesalahan jawaban.

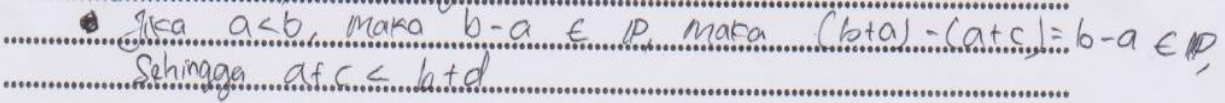

\section{Gambar 14. Jawaban Subjek KBIS}

Hal tersebut menunjukkan bahwa subjek KBIS belum mampu memeriksa kesahihan suatu argumen. Subjek KBIS mampu menemukan pola atau sifat dari gejala matematis untuk membuat generalisasi. Hal tersebut ditunjukkan oleh hasil pengerjaan secara tertulis dari subjek KBIS sebagai berikut.

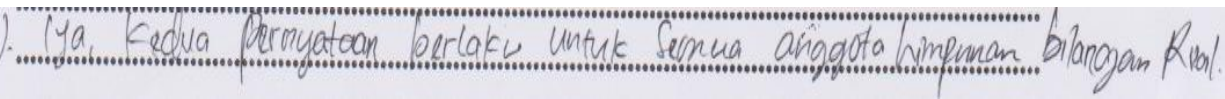

\section{Gambar 15. Jawaban Subjek KBIS}

C. Analisis Data Subjek dengan Kemampuan Berpikir Intuitif Rendah (KBIR) 
1. Memahami masalah

Pada tahap memahami masalah, subjek KBIR menuliskan hal yang diketahui dan yang ditanyakan dari masalah. Subjek KBIR dapat menuliskan bahwa yang diketahui adalah $\mathrm{a}, \mathrm{b}, \mathrm{c}, \mathrm{d} \in \mathbb{R}, \mathrm{a}<b$ dan $\mathrm{c} \leq \mathrm{d}$. Sedangkan pada yang ditanyakan, subjek KBIR dapat menuliskan bahwa yang ditanyakan $-(a+b)=(-a)+(-b)$, jika $\mathrm{a}<b$ dan $\mathrm{c} \leq \mathrm{d}$, maka $\mathrm{a}+\mathrm{c}<b+d$, dan apakah kedua pernyataan berlaku untuk semua anggota himpunan bilangan real. Hal tersebut sesuai dengan jawaban dari subjek KBIR sebagai berikut.

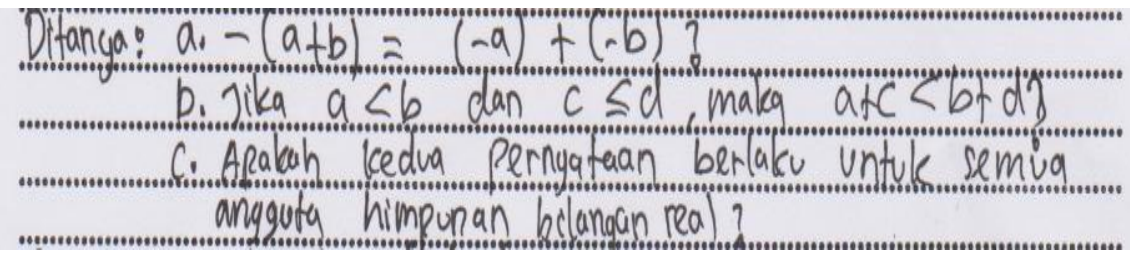

\section{Gambar 16. Jawaban Subjek KBIR}

Subjek KBIR juga dapat menentukan bahwa hal-hal yang diketahui sudah cukup untuk menjawab permasalahan yang ditanyakan pada soal. Hal ini dapat dilihat dari pekerjaan tertulis subjek KBIR yang mampu menyusun langkahlangkah pemecahan masalah dan melaksanakannya sehingga diperoleh hal yang ditanyakan, yaitu bukti dari dua pernyataan, yaitu $-(a+b)=(-a)+(-b)$ dan jika a $<b$ dan $\mathrm{c} \leq \mathrm{d}$, maka $\mathrm{a}+\mathrm{c}<b+d$. Berdasarkan hal tersebut, maka subjek KBIR mampu menuliskan apa yang diketahui dan yang ditanyakan, sehingga bisa dikatakan bahwa subjek KBIR mampu menyajikan pernyataan matematika secara lisan, tertulis, gambar, dan diagram.

2. Merencanakan penyelesaian

Subjek KBIR merencanakan penyelesaian terhadap dua masalah, yaitu membuktikan bahwa $-(\mathrm{a}+\mathrm{b})=(-\mathrm{a})+(-\mathrm{b})$ dan jika $\mathrm{a}<\mathrm{b}$ dan $\mathrm{c} \leq \mathrm{d}$, maka $\mathrm{a}+\mathrm{c}<b+d$. Dalam pembuktian $-(\mathrm{a}+\mathrm{b})=(-\mathrm{a})+(-\mathrm{b})$, subjek KBIR memulai perencanaan penyelesaian dengan menuliskan bahwa $-(\mathrm{a}+\mathrm{b})=$ $(-1)(a+b)$ kemudian menerapkan sifat distributif perkalian terhadap penjumlahan menjadi $(-1)(a)+(-1)(b)$, dan menerapkan kembali sifat $(-1)(a)=-a$. Pada pembuktian ini, subjek KBIR juga membuktikan bahwa $(-1)(\mathrm{a})=-\mathrm{a}$. Pembuktian ini dilakukan karena $(-1)(\mathrm{a})=-\mathrm{a}$ tidak ada pada aksioma himpunan bilangan real. Subjek KBIR telah mampu mengaitkan antara yang diketahui dengan yang dibuktikan meskipun belum benar.

Dalam pembuktian jika $\mathrm{a}<b$ dan $\mathrm{c} \leq \mathrm{d}$, maka $\mathrm{a}+\mathrm{c}<b+d$, subjek KBIR membagi $\mathrm{c} \leq \mathrm{d}$ menjadi dua kasus, yaitu $\mathrm{c}=\mathrm{d}$ dan $\mathrm{c}<d$. Pada kasus yang 
pertama, $\mathrm{c}=\mathrm{d}$, subjek KBIR menuliskan bahwa jika a $<b$, maka $\mathrm{a}+\mathrm{c}<b+d$. Subjek KBIR telah mampu mengaitkan antara yang diketahui dengan yang dibuktikan. Pada kasus yang kedua, $\mathrm{c}<d$, subjek KBIR mampu menuliskan bahwa a $+\mathrm{c}<b+c<b+d$ sehingga $\mathrm{a}+\mathrm{c}<b+d$. Pembuktian tersebut masih belum sempurna karena subjek KBIR belum menuliskan alasan dari pembuktian yang dilakukan. Uraian tersebut menunjukkan bahwa subjek KBIR belum mampu mengajukan dugaan tentang penyelesaian suatu masalah dengan sempurna, sehingga bisa dikatakan bahwa subjek KBIR belum mampu mengajukan dugaan.

3. Menyelesaikan masalah sesuai rencana

Subjek KBIR mampu menyelesaikan masalah sesuai rencana yang telah dibuat pada tahap sebelumnya. Dua masalah yang harus diselesaikan adalah pembuktian $-(\mathrm{a}+\mathrm{b})=(-\mathrm{a})+(-\mathrm{b})$ dan jika $\mathrm{a}<b$ dan $\mathrm{c} \leq \mathrm{d}$, maka $\mathrm{a}+\mathrm{c}<b+d$. Pada pembuktian $-(\mathrm{a}+\mathrm{b})=(-\mathrm{a})+(-\mathrm{b})$, subjek KBIR memulai pembuktian dengan menuliskan $-(\mathrm{a}+\mathrm{b})$ sebagai $(-1)(\mathrm{a}+\mathrm{b})$, kemudian subjek KBIR menerapkan sifat distributif perkalian terhadap penjumlahan sehingga didapat $(-1) a+(-1) b$. Subjek KBIR menerapkan lagi sifat $(-1) a=-a$ sehingga didapat $(-a)+(-b)$. Hal tersebut dapat dilihat pada pekerjaan tertulis subjek KBIR sebagai berikut.

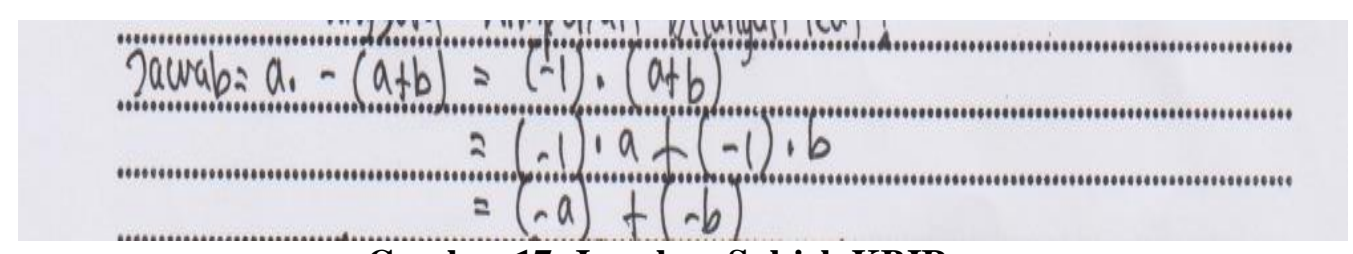

\section{Gambar 17. Jawaban Subjek KBIR}

Jawaban tertulis subjek KBIR seperti yang telah diuraikan di atas menunjukkan bahwa subjek KBIR belum mampu melakukan manipulasi aljabar pada penyelesaian masalah matematika. Hal ini terlihat dari ketidakmampuan subjek KBIR dalam menuliskan alasan dari setiap pembuktian yang dilakukan. Hal tersebut menunjukkan bahwa subjek KBIR belum mampu melakukan manipulasi matematika.

Pembuktian yang kedua adalah jika $\mathrm{a}<b$ dan $\mathrm{c} \leq \mathrm{d}$, maka $\mathrm{a}+\mathrm{c}<b+d$. Pada pembuktian yang kedua ini subjek KBIR membagi $\mathrm{c} \leq \mathrm{d}$ menjadi dua kasus, yaitu $\mathrm{c}=\mathrm{d}$ dan $\mathrm{c}<d$. Pada kasus yang pertama, $\mathrm{c}=\mathrm{d}$, subjek KBIR menuliskan bahwa jika $\mathrm{c}=\mathrm{d}$, maka $\mathrm{a}+\mathrm{c}<b+d$. Berikut ini adalah hasil pekerjaan tertulis subjek KBIR.

(1) 
Pada kasus yang kedua, $\mathrm{c}<d$, subjek KBIR menuliskan bahwa $\mathrm{a}+\mathrm{c}<b+d$.

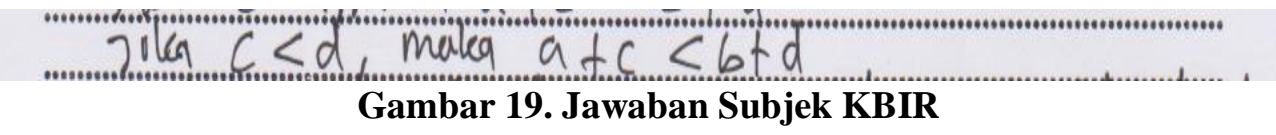

Hasil pekerjaan tertulis subjek KBIR tersebut menunjukkan bahwa subjek KBIR belum mampu menyusun bukti atas masalah matematika secara sempurna. Subjek KBIR juga belum mampu memberikan alasan atau bukti terhadap beberapa solusi. Hal ini dapat disimpulkan dari ketidakmampuan subjek KBIR dalam menerapkan sifat urutan pada himpunan bilangan Real pada pembuktian pernyataan jika $\mathrm{a}<b$ dan $\mathrm{c} \leq \mathrm{d}$, maka $\mathrm{a}+\mathrm{c}<b+d$. Subjek KBIR dikatakan belum mampu menarik kesimpulan, menyusun bukti, memberikan alasan atau bukti terhadap beberapa solusi.

4. Melakukan pengecekan kembali

Pada tahap melakukan pengecekan kembali, subjek KBIR mampu menarik kesimpulan dari pernyataan dengan sempurna. Subjek KBIR mampu menarik kesimpulan dari pembuktian $-(\mathrm{a}+\mathrm{b})=(-\mathrm{a})+(-\mathrm{b})$ dan jika $\mathrm{a}<b$ dan $\mathrm{c} \leq \mathrm{d}$, maka $\mathrm{a}+\mathrm{c}<b+d$. Hal ini terlihat pada hasil pengerjaan subjek KBIR sebagai berikut.

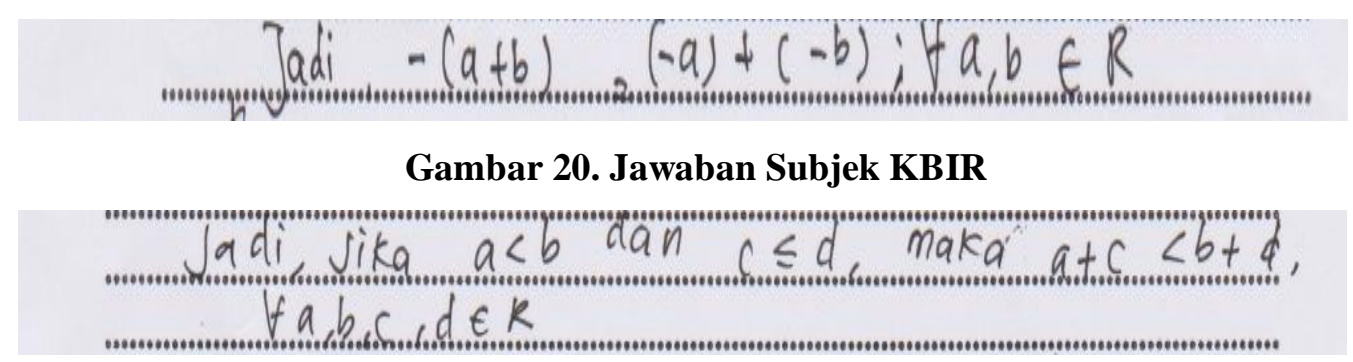

\section{Gambar 21. Jawaban Subjek KBIR}

Subjek KBIR memeriksa jawaban yang telah didapatkan pada tahap melakukan pengecekan kembali ini. Hal ini terlihat dari hasil pengerjaan soal tes penalaran matematis oleh subjek KBIR yang benar dan teliti, yaitu tidak ditemukan adanya kesalahan jawaban, meskipun pada pembuktian pernyataan yang kedua, subjek KBIR belum mampu membuktikan dengan sempurna. Hal tersebut menunjukkan bahwa subjek KBIR mampu memeriksa kesahihan suatu argumen. Subjek KBIR mampu menemukan pola atau sifat dari gejala matematis untuk membuat generalisasi. Hal tersebut ditunjukkan oleh hasil pengerjaan secara tertulis dari subjek KBIR sebagai berikut. 


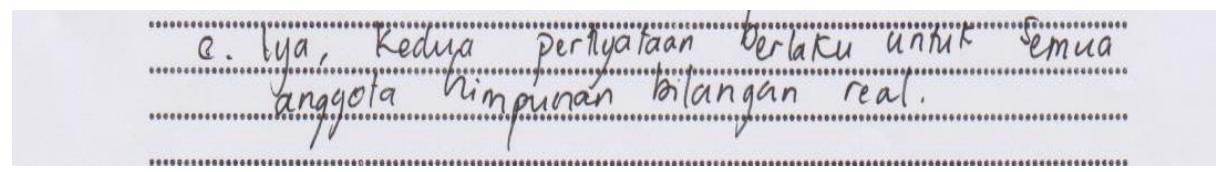

Gambar 22. Jawaban Subjek KBIR

\section{SIMPULAN DAN SARAN}

Berdasarkan hasil penelitian dan pembahasan yang diperoleh dapat diambil suatu kesimpulan penalaran matematis mahasiswa dalam memecahkan masalah analisis real ditinjau dari kemampuan berpikir intuitif sebagai berikut.

1. Mahasiswa dengan kemampuan berpikir intuitif tinggi pada pemecahan masalah analisis real memiliki kecenderungan melaksanakan penalaran matematis dengan sempurna. Mahasiswa dengan kemampuan berpikir intuitif tinggi mampu melaksanakan penalaran matematis pada setiap tahap pemecahan masalah analisis real.

2. Mahasiswa dengan kemampuan berpikir intuitif sedang pada pemecahan masalah analisis real memiliki kecenderungan melaksanakan penalaran matematis dengan kurang sempurna. Mahasiswa dengan kemampuan berpikir intuitif sedang tidak mampu melaksanakan penalaran matematis pada tahap pemecahan masalah menyelesaikan masalah sesuai rencana dan melakukan pengecekan kembali.

3. Mahasiswa dengan kemampuan berpikir intuitif rendah pada pemecahan masalah analisis real memiliki kecenderungan melaksanakan penalaran matematis dengan tidak sempurna. Mahasiswa dengan kemampuan berpikir intuitif rendah tidak mampu melaksanakan penalaran matematis pada tahap pemecahan masalah merencanakan penyelesaian dan menyelesaikan masalah sesuai rencana.

Berdasarkan hasil penelitian dan pembahasan sebagaimana yang telah disimpulkan di atas, peneliti menyarankan bagi penelitilain yang berminat dapat mencoba untuk menggali lebih lanjut dari penelitian ini atau dapat melakukannya pada tingkat dan materi yang berbeda dengan sudut pandang peninjauan yang sama atau sudut pandang peninjauan yang lain mengenai penalaran matematis mahasiswa.Hasil penelitian ini jugadapat digunakan untuk melakukan penelitian pengembangan berdasarkan temuantemuan yang diperoleh dalam penelitian. 


\section{DAFTAR PUSTAKA}

Marsigit. 2012. Kajian Peneltian (Review Jurnal Internasional) Pendidikan Matematika. http://staff.uny.ac.id/sites/default/files/pendidikan/Marsigit,\%20Dr.,\%20M.A. /Kajian\%20Penelitian\%20(Review\%20Jurnal\%20Internasional)\%20Pendidikan \%20Matematika_Matrikulasi\%20S2\%20Dikmat.pdf. diakses tanggal 12 Mei 2017

Moleong, Lexy J. 2012. Metodologi Penelitian Kualitatif. Bandung: PT Remaja Rosdakarya

Nasution, S. 2006. Berbagai Pendekatan dalam Proses Belajar Mengajar. Jakarta: Bumi Aksara

Rustandi, Ino. 2013. Pembelajaran Matematika dengan Menggunakan Model Reciprocal Teaching untuk Meningkatkan Kemampuan Penalaran Matematis Siswa SMP. http://repository.upi.edu/4331/4/S_MTK_054251_Chapter1.pdf Diakses tanggal 13 Juni 2107

Sugiyono. 2013. Metode Penelitian Pendidikan: Pendekatan Kuantitatif, Kualitatif dan $R \& D$. Bandung: Alfabeta

Sunarto. 2001. Metodologi Penelitian Ilmu-ilmu Sosial dan Pendidikan. Surabaya. Unesa University Press

Wulandari, Enika. 2011. Meningkatkan Kemampuan Penalaran Matematis Siswa melalui Pendekatan Problem Posing di Kelas VIII A SMP Negeri 2 Yogyakarta. http://eprints.uny.ac.id/1709/1/Enika_Wulandari.pdf. diakses tanggal 6 Mei 2017 